\title{
Evolución de la ritualidad del Tinkunaco. La Rioja, Argentina.
} (Siglo XVI hasta la actualidad)

\section{Evolution of ritual of the Tinkunaco. La Rioja, Argentina. (16th century to today)}

\author{
(i) JUAN CARLOS GIULIANO \\ Universidad Nacional de La Rioja \\ giovannigiulianoar@gmail.com
}

Resumen: El presente trabajo indaga la forma en que se estructuró ritualmente a través del tiempo la fiesta mayor de La Rioja (Argentina), conocida como Tinkunaco o Encuentro. Esta ceremonia, que se pretende inmutable durante 400 años, ha variado de distintas formas la organización de su ritualidad, con diferencias en el nivel de protagonismo de las élites y de los sectores populares, entendiendo por estos a sujetos sociales que tienen en común un lugar de subordinación en la relación económica, social o política. Se infirió una interpretación de los cambios, a partir del análisis de los objetivos del poder hegemónico de cada momento histórico, y cómo estos influyeron en su expresión desde de la colonización hasta el presente.

Palabras clave: Jesuitas, Tinkunaco, Encuentro, religiosidad, política.

\begin{abstract}
The present study explores the way in which the greater festival of La Rioja, Argentina, known as Tinkunaco or Encuentro, was ritually structured over time. This ceremony, apparently unchanged for 400 years, has however varied the organization of its rituality in different ways, with differences in the level of prominence of the elites and the popular sectors, understanding these as social subjects but that have in common a place of subordination in the economic, social or political relationship. The article makes an interpretation of the changes through the analysis of the objectives of the hegemonic power of each historical moment, and how these influenced its forms of expression from the colonial period to the present.
\end{abstract}

Keywords: Jesuits, Tinkunaco, Encuentro, religiosity, politics.

Recibido: 23 de septiembre de 2018; aceptado: 30 de junio de 2019; publicado: 30 de septiembre de 2019. Revista Historia Autónoma, 15 (2019), pp. 115-134 e-ISSN: 2254-8726; DOI: https://doi.org/10.15366/rha2019.15.006 
El mestizaje indio-español de La Rioja funciona siempre como paradigma del discurso historiográfico, aunque es una construcción mítica que altera la verdadera realidad otorgándole más valor del que tiene. Deriva de que, al igual que las otras ciudades americanas nacidas de la conquista española, es un espacio humano y geográfico fronterizo, desde de lo étnico, lo social y lo mental. Por ello funcionó, y continúa funcionando, la alteridad y el "descubrimiento" del "otro", tanto para los europeos como para los amerindios y africanos. Este descubrimiento nació con la invasión europea y se complicó con el tiempo y la diversidad de sujetos e identidades que conformaron las castas, pero que nunca derivaron en un encuentro entre estamentos ni etnias.

Tinkunaco, palabra que significa encuentro, es el nombre dado a unas celebraciones que son mezcla entre tradición, religiosidad y socialización. Su versión más multitudinaria, y en la que se centra este escrito, se celebra anualmente en la ciudad capital de la provincia de La Rioja (Argentina), entre el 31 de diciembre y el 3 de enero. Según la tradición, hace más de 400 años que se celebra de igual manera, sistematizada originalmente por los padres jesuitas para rememorar los acontecimientos sucedidos durante la Pascua de 1593, cuando los diaguitas, agobiados por los innumerables sufrimientos impartidos por los españoles, no soportaban más su trato y resolvieron atacar la ciudad. San Francisco Solano, de paso por La Rioja, tuvo la feliz idea de acordar la destitución de las autoridades españolas y nombrar alcalde de la ciudad al Niño Jesús para que gobernase con bondad; y así salvó a La Rioja de su destrucción. Ese, se dice, fue el primigenio "encuentro", indios y españoles se abrazaron. El Tinkunaco recrearía ese mítico hecho. Sale una procesión desde la catedral presidida por el obispo y san Nicolás, el patrono designado por los españoles, acompañado por promesantes llamados alféreces que llevan banderas atadas en señal de rendición, consistentes en una pica con globos de colores. Desde el templo de San Francisco sale otra procesión presidida por un jefe indio (el Inca) acompañado por su tribu (los allis) con la imagen del Niño Dios vestido como un alcalde español. Las imágenes se encuentran frente a la sede de Gobierno. Allí las autoridades "se rinden", delegando el mando de la ciudad. La imagen de san Nicolás y todos los asistentes se arrodillan tres veces para reconocer autoridad al Niño Alcalde, que es el único que queda de pie. Luego, todos aplauden y se abrazan sin distinciones de rango, y las imágenes se dirigen juntas a la catedral. Saludos protocolares, oficios religiosos y procesiones siguen esos días, hasta que el 3 de enero, ambas imágenes son sacadas de nuevo al frente de la sede de Gobierno, donde el Inca devuelve a las autoridades la llave de la ciudad y el bastón de mando, mientras el obispo toma el Evangelio y lo entrega diciéndoles “con esta Ley gobernarán”. Cumplido esto, las imágenes "se despiden" y cada una vuelve a su templo.

Esta celebración es una de las fiestas populares más originales e importantes de Argentina, o al menos, lo era hasta hace poco, cuando el poder político y la jerarquía eclesiástica pasaron a influir fuertemente en su organización y ritualidad; hasta ese momento era resultado casi exclusivo de la religiosidad espontánea de sectores populares. 
Los estudios realizados hasta el momento sobre el Tinkunaco han abordado el tema desde las dicotomías idolatría-dios verdadero, conquista-liberación y encuentro-opresión, con diferentes énfasis. Me propuse entonces una relectura crítica de los cronistas e historiadores, pero contrastándolos con otras fuentes, incluso orales y literarias, que abordan aspectos sociales, económicos y políticos de cada momento, que permitieron una ubicación espacial y social, sobre todo para cubrir el hiato documental anterior a mediados del siglo xIx. Usé para ello el método descriptivo inferencial, con el objetivo de indagar sobre diferentes variables. El aporte del trabajo consiste en el enfoque del proceso de larga duración tratando de determinar quién se benefició con los cambios que se fueron incorporando a la ritualización.

En general, los autores replicaron, con pequeñas diferencias, el relato oficial sobre el origen y significado de esta festividad, poniendo acento en la faceta sincrética, sosteniendo que fue una creación española que generó un mestizaje cultural simpático y amigable, dejando entrever que el mismo se dio a nivel político, institucional y social, sin dar lugar hoy a reivindicaciones culturales, y menos políticas, asentadas en la descolonización ${ }^{1}$. Unos pocos lo destacan como ejemplo de legitimación de acuerdos sociales y confirmación de la separación de $\operatorname{castas}^{2}$; y un solo autor ${ }^{3}$ insiste en la importancia política de la fiesta, y desde una cosmovisión andina añora la idiosincrasia y la estructura social prehispánica con un fuerte discurso indigenista, apoyando la conflictiva situación actual de resistencia cultural, que será prolegómeno de resistencia política. Parecía necesario, entonces, analizar los cambios ocurridos en el tiempo interpelando a la dimensión ideológica de la festividad, así como explicarla y fundamentarla desde el punto de vista de su utilización como factor legitimador de la posición de poder sobre los sectores populares.

\footnotetext{
${ }^{1}$ Cáceres Freyre, Julián, "El Encuentro o Tincunaco. Las fiestas religiosas tradicionales de San Nicolás de Bari y el Niño Alcalde en la ciudad de La Rioja", en Separata de Cuadernos del Instituto Nacional de Antropología, 6 (1966-1967), pp. 253-338; Gálvez, Manuel, La Maestra Normal, Buenos Aires, Editorial Patria, 1921; González, Joaquín Víctor, Mis Montañas, Buenos Aires, Atlántida, 1971; Ortiz, Juan Aurelio, Tinkunaco riojano, Córdoba, Tiempo Latinoamericano, 1987; Ponce, Jorge, El Encuentro o Tinkunaco en Aminga, La Rioja, Instituto del Folklore Riojano, 1981; Valdés, Carmelo B., Tradiciones Riojanas: Blancos y negros, Buenos Aires, J. Lajouane \& Cía., 1916; Vera Vallejo, Juan Carlos, Las fiestas de San Nicolás en La Rioja, La Rioja, Obispado de La Rioja, 1983.

${ }^{2}$ De la Fuente, Ariel de la, Los hijos de Facundo: Caudillos y montoneras en la provincia de La Rioja durante el proceso de formación del Estado nacional argentino (1853-1870), Buenos Aires, Prometeo, 2014; Gentile, Margarita, "ACTAS de alianza entre indios y españoles (Gobernación de Tucumán, siglos XVI y XVII)", en Bibliographica Americana, 7 (2011), pp. 64-86; Oguic, Sofía Rufina, El Tinkunaco: La fiesta del Encuentro, Buenos Aires, El Trabajador, 2006.

${ }^{3}$ Ponce, Jorge, El Tinkunaco ¿Encuentro o encontronazo?, La Rioja, Nexo Ediciones, 2009.
} 


\section{Una colonia española}

La celebración tiene un origen que no pudo ser determinado aún, pero "se acotaría el evento entre 1591 (fundación de la ciudad) y 1595 (regreso de San Francisco Solano a Lima)"4. Es verosímil que la concentración de 45 caciques con sus gentes - 9.000 indios — en la ciudad que había sido fundada hacía poco tiempo, no se debiera a un alzamiento o a una guerra que la pusiera en peligro, sino al fervor y curiosidad que en ellos despertó la presencia de Fray Solano para predicar. Ello se desprende del proceso de canonización del santo, conocido de los pueblos originarios por su bondad y defensa de sus intereses, según los testimonios franciscanos 5 (aunque estos puedan ser sospechados de cierta parcialidad). Sostener que no hubo un episodio de alzamiento, no invalida el temor del estamento español ante tamaña concentración de pueblos originarios. Este primer encuentro interétnico se habría producido en la plaza, y no en el sitio que demandaba la tradición, actualmente conocido como Las Padercitas, a una legua de ella, reuniendo a indios y caballeros españoles. El proceso de conversión de los indios para su bautismo habría durado un tiempo, hasta concluir, con gran algazara, el domingo de Pascua ${ }^{6}$, pues es bien conocida la costumbre de topamientos y borracheras rituales en celebraciones. Así pues, es posible que todo concluyera en una verdadera fiesta tal como luego lo reglarían las Ordenanzas de Alfaro de 1612, permitiendo que en fiestas y ocasiones de regocijo celebradas en plazas y lugares públicos se juntasen a holgarse y beber. Los jesuitas habrían formalizado la conmemoración del hecho, aunque ellos fueron la última orden religiosa que se asentó en La Rioja, en 1624, debido a su postura a favor de la evangelización del indio con actitud paternalista.

Existía antes de la colonización una tradición indígena de batallas rituales, que se realizaban en el solsticio de diciembre, reafirmando la sucesión en orden del poder político; conmemoraban la victoria del joven Inca, que asumía el mando, sobre sus enemigos que traían destemplanza y malas cosechas. Este joven gobernante debía, al menos simbólicamente, reconstruir el orden social y político ${ }^{7}$. Los jesuitas conocían esta celebración y la habrían aprovechado mediante la reproducción del mismo esquema, enfatizando la categoría de lo simbólico en vez de lo histórico, es decir, la categoría del mito. Esto daría lugar a la representación, y lo relacionaría análogamente con los diferentes sistemas de signos que permitieran modos de producción ideológica, de funcionamiento y de recepción de los sistemas semióticos. "Tomar elementos indígenas e incorporarlos a prácticas que servían para difundir y afianzar la religión y la fe, ha

\footnotetext{
${ }^{4}$ Gentile, Margarita, “ACTAS de alianza... op. cit., p. 75.

${ }^{5}$ Caggiano, Antonio, "La Figura de San Francisco Solano y su actuación en el Tucumán, según el proceso de beatificación y canonización instruido en Lima y conservado en los Archivos Vaticanos de la Sagrada Congregación de Ritos", en Boletín de la Academia Nacional de la Historia, XXIV, Año XXVI (1950-51), pp. 146-156.

${ }^{6}$ Palacios, Ernesto, Estampas de La Rioja colonial, La Rioja, Nexo Grupo Editor, 2010.

${ }^{7}$ Duviols, Pierre, "Del discurso escrito colonial al discurso prehispánico: Hacia el sistema sociocosmológico inca de oposición y complementariedad", en Bulletin de l'Institut français d'études andines, 26 (1997), pp. 279-305.
} 
sido uno de los componentes identificadores de la evangelización jesuítica"8. Apoyados en esa costumbre de fiestas andinas, concentraban anualmente gran cantidad de indios en las plazas de los curatos para facilitar la evangelización con sermones y festejos. La fecha coincidía con el recambio de las autoridades capitulares españolas; el joven Inca fue simbólicamente sustituido por un joven Niño Dios, la celebración garantizaba la transición hacia un nuevo orden social y político. Hay quien sostiene que pudo tener un origen más europeo que andino, al entenderlo como un "acta de alianza", asimilable a la ceremonia medieval de "pleito homenaje". Quizás la mixtura de andino y europeo sea el origen real, aportando cada uno una parte.

Los jesuitas estaban muy capacitados, y representaban ideológicamente lo más avanzado del clero a favor de la modernidad. Eran totalmente opuestos a la mentalidad feudal de la mayoría de los conquistadores. La concepción feudal concebía a los indios colectivamente como siervos para el trabajo, mientras que la propuesta de los jesuitas preveía su transformación en individuos insertos en un nuevo modo de producción. En ese sentido, aunque mostraran una defensa paternal del indio, reforzarían el concepto eurocentrista de raza y el deber civilizador de los invasores ${ }^{10}$. La categorización racial consistió en enfatizar el "no eres como yo", porque de ello se desprendía, por tanto, que era inferior; una visión paternal cristiana de la humanidad que incluía, aunque en distinto nivel, a los indios americanos y a los negros africanos, apoyada en el concepto de otredad. Cuando analizamos los términos de la relación de poder dentro de ese contexto de esquema asimétrico, se hace evidente la violencia simbólica ejercida. Resulta entonces poco verosímil hablar de "encuentro". La tolerancia, la conveniencia e incluso el estímulo de expresiones de religiosidad segregadas entre "unos" y "otros", producen la esencia de la noción de colonialidad, con el objetivo de caracterizar un patrón de dominación propio del mundo moderno y del sistema capitalista, originado con el colonialismo europeo a principios del siglo Xvi; se percibe también una intención dominadora al ritualizar el Encuentro.

\footnotetext{
Los jesuitas, he dicho, recogieron aquel suceso para darle forma tangible y práctica en el gobierno y en la religión; para combinar los elementos salvajes con los cultos de aquella leyenda, y para hacer entrar en la obscura conciencia de los indios la idea de las dos potestades que gobiernan las sociedades humanas. La idea del Niño Jesús convertido en Alcalde del mundo es algo que sale de los límites de una invención vulgar y sencilla; despierta trascendentales raciocinios, proyectando desarrollos vastísimos en el orden de las reflexiones filosóficas. El municipio fue la primera forma de gobierno civilizado [...] y era sentar las bases, los puntos de partida de los futuros gobiernos hispanoamericanos. ${ }^{11}$
}

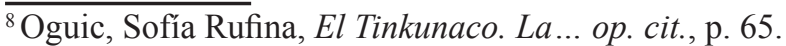

${ }^{9}$ Gentile, Margarita, “ACTAS de alianza... op . cit., p. 68.

${ }^{10}$ Giuliano, Juan Carlos, Arqueología de la colonialidad. La dinámica social y las relaciones interétnicas coloniales plasmadas en la arquitectura y el paisaje arqueológico del sitio Estancia jesuitica "La Saladilla”, en La Rioja, Argentina, Trabajo Final de Licenciatura en Historia con orientación en Arqueología, Universidad Nacional de La Rioja, 2016; Ponce, Jorge. El Tinkunaco ¿Encuentro o... op. cit.

${ }^{11}$ González, Joaquín Víctor, Mis Montañas... op. cit., pp. 98-99.
} 
Los Encuentros se celebraban no solo en La Rioja — este eray es el de mayor magnificenciasino en los pueblos sedes de curatos coloniales. Las celebraciones poseían — como perdura aún en San Blas de los Sauces - un aspecto popular y participativo, y se complementaban con ferias y fiestas; hasta los 70 del siglo xx se continuaban realizando ferias en la plaza de La Rioja. Incluían bailes y la participación de figuras de gigantes caricaturescos; en ellas se parodiaban escenas históricas referidas a la conversión de los indios al cristianismo y las ventajas de la nueva fe. El uso de imágenes en andas fue la forma de transculturar la procesión de las huacas de sus ancestros, paseadas en fechas festivas por los pueblos indígenas ${ }^{12}$. Se incorporó así el concepto de dios europeo y nuevo sistema político, y es posible inferir la intensa y profunda relación entre lo simbólico y lo social. La fiesta discurría en la plaza y las calles aledañas. En esencia, puede interpretarse que lo que ocurría en la plaza fundacional y sus inmediaciones, repetía lo que ocurría en las fiestas agrícolas, como las de cosecha o chaya, que se celebraban ritualizando una amalgama entre ceremonias autóctonas ancestrales y formas superpuestas de espectáculos organizados de cierta manera cómica durante la Edad Media europea - y que en países como España destacaban por su riqueza y complejidad-, y habían sido trasplantadas por la tradición de los conquistadores. De estas fiestas no hay registros documentales y la única forma de reconstrucción es apelar a la metodología inferencial como en arqueología.

Este rito tenía intencionalmente mucho poder simbólico, políticamente celebraba el nuevo orden social, consolidaba la alteración de valores en la cosmovisión y justificaba el usufructo del trabajo indígena. El festejo hacia coincidir la celebración prehispánica del solsticio de diciembre con sus batallas rituales en conmemoración del infante Yupanqui, asumido como Inca, con las celebraciones cristianas y el recambio de las autoridades coloniales cada fin de año. Con estos nuevos significados pasó a ocupar un lugar importante en la vida de los sectores populares. Los festejos atemperaban la desigualdad, el racismo, la violencia y la discriminación, resaltando la ideología evolutiva de la modernidad.

Fue un proceso que se realizó en el interior de la cultura por medio de las identificaciones, influyendo en la constitución psíquica. El ritual propuesto por los jesuitas y del cual se apropiaron los pueblos originarios, los distanció cada vez más de su propia cultura. Con la inclusión de algunos saldos de la cultura aborigen — como santos en andas - se posibilitó la satisfacción de dos instancias psíquicas a la vez, la consciente cristiana y la previa, pagana. Funcionando a la manera de un síntoma que sostiene en el engaño una verdad velada, que los sujetos no podían hacer consciente ${ }^{13}$. La celebración se basaba fundamentalmente en algarabía, festejo, y sensación colectiva de felicidad y bienestar, posible sobre todo porque un sector importante de los sujetos compartía sus nuevas creencias. Un elemento constante de la conquista desde el siglo XVI ha sido el esfuerzo de reconciliar el mundo de los dominadores y

\footnotetext{
${ }^{12}$ Valenzuela Márquez, Jaime, “Cruces contra Huacas en la cristianización antiidolátrica del Perú", en Boletín del Instituto Riva-Agüero, 32 (2005), pp. 12-33.

${ }^{13}$ Leda Giuliano Ferrari, la estructura psicológica del grupo social fue desarrollada en entrevista personal con el autor, La Rioja, 20 de julio de 2017.
} 
el de los dominados en términos de una unidad que, apuntando a la idea de felicidad individual, al mismo tiempo anulaba las diferencias aparentes y fortalecía la dominación. Esta corriente ideológica que reflejaba el pensamiento del Renacimiento y de la Contrarreforma, fue sostenida por los jesuitas, que establecieron modelos para permitir integrar al dominado en el curso de la historia eurocéntrica, y daría como resultado para los americanos, sujetos hábiles para la reproducción capitalista. "La conquista ritual, como denominaremos a esta estrategia, puede ser tan importante como el control de la infraestructura y recursos económicos y militares"14.

Los jesuitas fueron muy efectivos colonizadores, pues organizaron la evangelización con un concepto de reconciliación de culturas, partiendo de la originaria para transformarla en europea, con todo el bagaje cultural y económico que eso implicaba como transculturación. La participación masiva en festividades con organización supervisada y ritualización intervenida fue parte del modelo evangelizador jesuita, al superponer a ellas un programa destinado a legitimar la nueva cosmovisión y los nuevos modos de producción.

Al uso de las ciudades españolas yo comencé a introducir en mi pueblo la costumbre de realizar anualmente una procesión a objeto y fin que los indios como vasallos españoles presentaran al Rey de España una especie de homenaje [...]. Lo mismo como yo me había empeñado en inspirar en las procesiones eclesiásticas a los indios una sumisión a Dios, Señor del Cielo, quise empeñarme en darles también una idea de en qué modo debían mostrarse respetuosos ante un Jefe de la Tierra y rendirle homenaje. ${ }^{15}$

Leemos al respecto de las fiestas con participación popular:

Todos estos ritos y espectáculos organizados a la manera cómica, presentaban una diferencia notable, una diferencia de principio, podríamos decir, con las formas del culto y las ceremonias oficiales serias de la Iglesia o del Estado feudal. Ofrecían una visión del mundo, del hombre y de las relaciones humanas totalmente diferente, $[. .$.$] en la que vivían en fechas determinadas. Esto creaba$ una especie de dualidad del mundo. ${ }^{16}$

Mijail Bajtin ${ }^{17}$ destaca la aparente escasa diferencia entre estamentos sociales en las celebraciones, y el protagonismo que adquirían las imágenes que cobraban vida, ya que los homenajes las convertían casi en objetos de blasfemia, que él llamó "risa ritual". Más que rendírseles culto, eran un personaje más de la fiesta. Pero lo más importante era el hecho de la

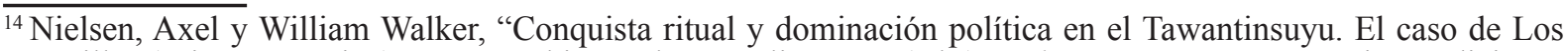
Amarillos (Jujuy, Argentina)”, en Zarankin, Andrés y Félix Acuto (eds.), Sed Non Satiata, Buenos Aires, Ediciones del Tridente, 1999, pp. 153-169.

${ }^{15}$ Paucke, Florian, Hacia allá y para acá. Una estada entre los indios mocobies (1749-1767), Tomo II, Tucumán, Universidad Nacional de Tucumán, 1942-1944, p. 256.

${ }^{16}$ Bajtin, Mijail, La cultura popular en la Edad Media y en el Renacimiento, Madrid, Alianza Editorial, 1987, p. 8

${ }^{17}$ Ibídem.
} 
desaparición de toda distinción entre homenajeados, actores y espectadores, todos participaban y vivían el rito.

Dentro de este contexto, por la elección de las imágenes para animar la fiesta, ya sea San Nicolás, el Niño Alcalde, o gigantes cabezones hoy abolidos, se puede conjeturar que no respondió a la recreación del hecho histórico, sino a su celebración y exaltación. El color negro para el rostro de San Nicolás habría obedecido a la "risa ritual" que finalmente es la forma fundamental de expresión de la cosmovisión y la cultura popular. Al respecto el folklorólogo riojano Faustino Gómez al describir la figura del Pujllay, dios que preside la Chaya, fiesta popular riojana por antonomasia, hizo notar la impronta de la "risa ritual":

Aquellas imágenes del dios talladas por los indios en madera o cerámica,
han degenerado en muñeco ridículo. El aspecto general es de viejo andrajoso
vestido con harapos. Pero algunos detalles tienden a darle cierta prestancia y
dignidad, no se lo viste con hojotas que representaría lo indígena, sino con
botas o zapatos, y sombrero amplio de ala requintada. ${ }^{18}$

Las fiestas oficiales de fin de año tenían que ver con un Niño (25 de diciembre), recambio de Alcalde (1 de enero), y san Nicolás (6 de diciembre), pero las autoridades civiles y de la Iglesia cuidaron siempre de mantener totalmente separados estos festejos populares. Esta confrontación de celebraciones reforzaba las diferencias estamentales, tanto que hasta principios del siglo xx, la procesión oficial de san Nicolás, como patrono tutelar, se realizaba presidida por autoridades y clero, portando una imagen de san Nicolás blanco.

La estrategia jesuita se apoyaba en la fuerte religiosidad cotidiana de los pueblos americanos, que casi carecían de una ritualidad pública como tenía la religión cristiana, pero poseían una acendrada espiritualidad que los contactaba con el mundo de los espíritus formando una relación especial con ellos, que los incluía como partes del armonioso equilibrio del hábitat, sus congéneres, ancestros y gobernantes, y de esta forma impulsaba la esperanza que todo iba a mejorar en el futuro. Tan fuerte fue la identificación con estas fiestas populares que expulsos los jesuitas en 1767, se organizaron ellos mismos para continuar realizándolas.

Llaman la atención las fuertes analogías que interceptan estos festejos con los de la Chaya, fiesta popular coincidente con el carnaval europeo. En la Chaya se reconoce también el Encuentro ritual. Dice el folklorólogo Gómez:

En el lugar elegido para la "coronación", por lo general la calle, se levantan arcos clavados en el suelo. Se acercan los compadres, héroes de la fiesta, escoltados por sus respectivas pacotas, las que atruenan el aire con sus cánticos e instrumentos diversos y haciendo estallar cohetes. Los compadres portando sendas coronas de albahaca y flores, recorren tres veces el trayecto. A la tercera vez, al llegar los compadres a los arcos, se hace un profundo silencio,

\footnotetext{
${ }^{18}$ Gómez, Faustino, Fiesta de la Chaya, escrito inédito, 1981. p. 26. Fotocopia de un manuscrito que me entregó su autor en entrevista en La Rioja el 26 de agosto de 1984.
} 
las pacotas se detienen, el conjunto ejecuta la vidalita, los compadres a paso lento y acompasado se acercan, se dan la mano, y juntan sus frentes. Entonces menudean los ¡Vivas! Y arrecian los instrumentos. ${ }^{19}$

En los dos casos se repiten algunas constantes que se entroncan con la tradición prehispánica de las batallas rituales. Como puede verse, la similitud entre los compadres en la Chaya y los santos del Tinkunaco es casi total.

La Rioja contó desde su fundación con población indígena intramuros. En el repartimiento de solares se incluyó a "indios amigos" y varios pueblos indígenas tenían su territorio lindante con la ciudad. Esta situación contribuyó desde los orígenes, a que grupos subalternos, formados al principio por indios y esclavos, a los que se agregaron los mestizos, tuvieran fuerte presencia en la vida urbana, y para fin del año, según decía el misionero jesuita Alonso de Bárzana, era el tiempo de la algarroba, cosecha fundamental para el indio.

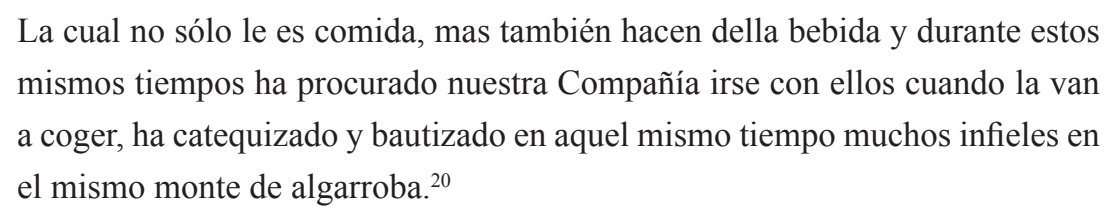

Seguramente este acompañamiento permanente de los jesuitas haya sido la base de la organización de la celebración urbana de fin de año.

Los Tinkunacos desde este análisis, nacieron como fiestas populares inducidas con un fin colonizador, superponiendo una tradición medieval europea a la religiosidad prehispánica de batallas rituales, que reafirmaban la sucesión natural del poder, reconstruyendo simbólicamente el orden social y político. Estas celebraciones llenaban las plazas y las calles durante varios días, donde la negritud del santo encontraría su explicación.

Todas estas celebraciones diferían notablemente de los ritos oficiales de la Iglesia o del Estado, y ofrecían una visión de las relaciones humanas totalmente diferente. Estas cualidades son las que dieron a la celebración el carácter de fiesta popular genuina, y garantizaron la continuidad. Los jesuitas, eminentes teólogos, habían partido de la realidad para elaborar su pastoral y organizaron la ceremonia como celebración, rememorando la conversión ${ }^{21}$. La intención fue el dominio de las mentalidades con sesgo para establecer la base de autoridad sobre los originarios.

Utilizando ciertos anacronismos en los relatos y apoyados en testimonios poco objetivos, ya desde las primeras descripciones modernas, los cronistas — que son políticos o religiososse esfuerzan por encajar los acontecimientos con cierto orden, para que la organización no se vea

\footnotetext{
${ }^{19}$ Ibídem, p. 30.

${ }^{20}$ Alonso de Bárzana, citado por Robledo, Víctor Hugo, La Rioja indígena. Origen, conquista y persistencia, La Rioja, Nexo Ediciones, 2007, p. 218.

${ }^{21}$ Ortiz, Juan Aurelio, Tinkunaco Riojano... op. cit.; González, Joaquín Víctor, Mis Montañas... op. cit.
} 
como espontánea o popular, sino como creación de dirigentes. Esto dará posterior justificación para intervenir encauzando la festividad para convertirla en rito oficial.

El hecho que conmemora y su ritualización, con pequeñas variaciones es aceptado por los historiadores, considerando que representó ritualmente una lucha de poder. El invasor fue portador de dos formas filosóficas distintas de encarar la conquista. Por un lado, la que asumían civiles, militares y algunas órdenes religiosas de prosapia feudal consistente en la imposición inmediata, por la fuerza, de una nueva cosmovisión, aunque lograrlo llevaba a la explotación hasta el aniquilamiento de los originarios. La segunda era la propuesta jesuítica para el mismo fin, pero conformada en la modernidad, consistente en la transformación del conquistado en súbdito, capaz de aprehender la cultura europea y aportar a su desarrollo, para lo cual se usaban métodos sin violencia física, y de resultados mucho más efectivos a largo plazo. La fiesta que hoy conocemos como Tinkunaco es un buen ejemplo de esta segunda estrategia. En su devenir histórico reflejó las posiciones de poder no solo entre conquistadores y conquistados, sino entre los propios conquistadores, franciscanos y jesuitas en primer lugar. La expulsión de los jesuitas que organizaban estas verdaderas fiestas populares con fines de evangelización demostró lo acertado de su estrategia, por cuanto las mismas se siguieron realizando, organizadas por los líderes naturales de los sectores populares. El contenido religioso se siguió manteniendo, y hasta acrecentando, aunque cabe inferir que adquirió cada vez más un carácter contracultural, o al menos de aglutinador social, a pesar del cambio que significó la disolución de la etnia originaria, y su reemplazo por negros africanos que habían llegado como esclavos, los cuales se fueron mixturando en infinidad de mestizaciones.

\section{La independencia}

El período que transcurre entre la expulsión de los jesuitas y el siglo xIX es de oscuridad total respecto a menciones escritas sobre la fiesta, aunque la misma continuó celebrándose. Caben solo conjeturas con racionalidad arqueológica apelando a distintas fuentes indirectas para concluir que la celebración tomó cada vez mayor carácter de fiesta popular. La Iglesia como institución la abandonó a su suerte, ya que para esa época había declinado su celo de "extirpación de idolatrías", y el Estado borbónico pensaba en recaudar, roto el compromiso de cruzada evangelizadora de la católica dinastía anterior. Así continuó el festejo popular, aunque cambiada la composición social. Los indios eran una minoría, creciendo el estamento de negros, mestizos y mulatos, que pasaron del $20 \%$ de la población total al $47 \%$, superando en conjunto al resto de los otros grupos sociales. Esta casta era muy pobre al punto de pasar 
hambre, desarrollaba actividades de subsistencia y tenía acceso limitado a la tierra. Eran agricultores, criadores y artesanos, peones o arrieros, todo al mismo tiempo ${ }^{22}$. Las cofradías organizadoras, si bien habían sido suprimidas y prohibidas por las autoridades eclesiásticas $\mathrm{y}$ civiles ${ }^{23}$, continuaron de hecho funcionando, y fomentaron el desarrollo de sentimiento de pertenencia e identificación, elemento de cohesión social que facilitó la elaboración de una identidad grupal muy fuerte, reflejada posteriormente en la aparición de conflictos étnicos y sociales que derivaron en luchas políticas violentas.

Desde la independencia en 1816 y las luchas civiles siguientes, la fiesta gestionada por los sectores populares organizados en cofradías no institucionalizadas, consistía en "juntas y borracheras", juegos y competencias de destreza - cuyo resabio hoy se mantiene en las competencias de caballos entre alféreces - y mascaradas que dispersas por las calles asustaban niños y creaban zozobra en los adultos, con gestos y vocabulario subidos de tono, seguramente de fuerte contenido erótico, al menos a criterio de la moral del momento. Todo este desborde solo cabe imaginarlo con la anuencia explícita de las autoridades civiles que seguramente corrían con buena parte de los gastos de la organización, continuando la tradición de reciprocidad andina en la generación de clientelismo. Esto se desprende de la descripción irónica cargada de prejuicios de los intelectuales de la época:

[...] el Inca entonces se toma unas horas de recreo, yendo a presentar sus saludos oficiales al gobernador de la Provincia, quién le recibe con respeto, y le habla de su dinastía. ${ }^{24}$

\begin{abstract}
En la sala de recepciones el gobernador y todos los presentes escuchaban de pie. Los indios cantaban al son monótono del tamborcito: Año nuevo pacari. Niño Jesús Canchan, Tintillalli llallincho, Corollalli llallincho... Era un canto doloroso, evocador, bárbaro, pleno de carácter [...]. Cuando terminaron se les dio cerveza y vino. La concurrencia se dispersó y los hombres se dirigieron a una calle próxima donde se efectuarían las carreras. ${ }^{25}$
\end{abstract}

Durante este período se produce una fuerte unificación de factores de etnicidad, capacidad económica y religiosidad, con los postulados políticos. Así gauchos, negros, pobres y católicos fueron federales; y los blancos, masones, ricos, y liberales eran unitarios. Esta construcción ideológica potenció el conflicto intraélites en competencia por el acceso a los recursos del Estado en formación. Un sector apoyó la relación clientelar, propiciando formas tradicionales de vida, la reivindicación de la herencia hispánica, y el intercambio de asistencia y

\footnotetext{
${ }^{22}$ De la Fuente, Ariel de la, Los hijos de Facundo... op. cit.

${ }^{23}$ Juan Aurelio Ortiz fue secretario del Obispado de La Rioja, asesor del obispo Angelelli para el ritual del Tinkunaco y director del Museo Histórico Castro Barros de Chuquis (LR). Entrevista realizada por el autor, La Rioja, 27 de marzo de 2018.

${ }^{24}$ González, Joaquín Víctor, Mis Montañas... op. cit., p. 103.

${ }^{25}$ Gálvez, Manuel, La Maestra Normal... op. cit., pp. 285- 286.
} 
protección, que devendría en el federalismo, o sea, la coalición de provincias autónomas, y en el caudillismo como expresión política. En oposición, el sector de élites liberales, modernizadoras, anticlericales, políticamente unitarias apoyaban un poder central fuerte $\mathrm{y}$, sin apoyo popular, desarrollaron fuertes vínculos con el Gobierno nacional ${ }^{26}$. La relación clientelar no aparece documentada en relación con la fiesta, pero es dable inferirla por el crecimiento de esta en detrimento de los actos oficiales, lo que solo sería posible con apoyo del único poder real, los caudillos, legitimados a su vez por esa demostración de adhesión popular.

Según refiere Manuel Barrios ${ }^{27}$, en ese momento era muy importante la devoción a un Niño Dios vestido con ropas de alcalde, propiedad de la familia Mercado residente a 40 kilómetros de la ciudad, que era bajada en procesión cada año para la Circuncisión del Señor ${ }^{28}$, momento en que se "encontraba" con san Nicolás negro. Este acontecimiento implicaba a una multitud de promesantes, peones y habitantes rurales, que se referenciaban como indios o "naturales", y recreaban la batalla ritual al modo peruano, en su encuentro con la imagen de san Nicolás venerada en la ermita a una cuadra de la plaza, para culminar en fiestas de borracheras.

\begin{abstract}
Se reunían alrededor de los árboles. Algunos comían sucias pastas compradas a vendedores ambulantes y que era preciso disputar a las moscas. Una mujer vendía sandías y melones, y un turco, bajo un gran parasol, ofrecía todo a veinte $[. .$.$] . A lo largo de las veredas se había colocado la concurrencia. En$ un extremo de la calle sin empedrar amontonábanse los alféreces. De pronto arrancaron dos hombres a caballo. Daban alaridos salvajes y se atropellaban con los caballos. La gente reía y aplaudía. Detrás salieron otros y otros después. Había una nube de tierra, un calor horrible [...]. Fue a los bailes tradicionales de aquella noche. Visitaron cierta casa donde se celebraba una aloja. Era una reunión clásica, con baile y borrachera, para saborear las primeras copas de aquel castizo brebaje $[\mathrm{sic}]{ }^{29}$
\end{abstract}

La fiesta devino en generadora de identidad étnica y aglutinadora de los sectores populares, utilizando sus creencias sincréticas como fuente de identidad tradicional, y usada para cierto acceso a la estructura de poder. Poder que a su vez redescubrió la tradición andina de reciprocidad y complementariedad para crear un esquema clientelar en las relaciones asimétricas. El caudillismo de raigambre federal daba gran importancia a las tradiciones religiosas católicas, y eso incentivó seguramente las manifestaciones públicas de fe, que redundaban en socialización vertical y adhesiones a la causa.

\footnotetext{
${ }^{26}$ De La Fuente, Ariel, Los hijos de Facundo..., op. cit.

${ }^{27}$ Barrios, Manuel, director del museo franciscano Inca Huasi. Entrevista realizada por el autor, La Rioja, 27 de mayo de 2018.

${ }^{28}$ En el calendario romano el 1 de enero era festividad de la Circuncisión de Jesús hasta la reforma del Calendario en 1960. La tradición oral refiere que la familia Mercado provenía de judíos conversos y por eso daba mucha importancia a esta presentación de Jesús al templo.

${ }^{29}$ Gálvez, Manuel, La Maestra Normal... op. cit., pp. 282, 286 y 290.
} 
3. Civilización o barbarie

Hacia 1880, la organización de la fiesta ya no era una acción espontánea comunitaria, corría por cuenta de la familia Nina, que detentaba el cargo de Inca, máxima autoridad de la fiesta, colaborando las cofradías informales. Era responsabilidad del Inca la representación de los acontecimientos históricos. Los atuendos no trataban de copiar a indios o a españoles, sino que incorporaron elementos simbólicos que hicieran comprensible el mensaje al pueblo. Indios y negros ya eran minoría frente a mestizos, mulatos y criollos gauchos que vivían en los ranchos de las afueras ${ }^{30}$. Cada detalle de la celebración se ejecutaba de acuerdo con una tradición que se trasmitía oralmente. Ninguna autoridad de la Iglesia ni del Estado participaba. Solo el pueblo la vivía.

Las élites autoexcluidas "porque consideraban deprimente de su dignidad e incompatible con su autoridad" ${ }^{11}$ sentían "esta fiesta popular semibárbara como reliquia viviente de aquellos tiempos nebulosos" ${ }^{32}$, porque "sus rostros indígenas revelaban la miseria de su raza, las devastaciones del alcohol, la tristeza de la vida rural" ${ }^{13}$, y comenzaron a encauzarla mediante prohibiciones explícitas.

En la guerra civil habían triunfado los unitarios y el capitalismo inglés, "la civilización". El lema "orden y progreso" se opuso a "los bárbaros". La acción principal de los festejos se estructuró con desfiles, procesión, y fiesta ordenada, el primer día del año a las 13 horas con el encuentro de los santos:

\footnotetext{
En dos filas paralelas, a ambos costados de la calle, venían como doscientos hombres a pie. Llevaban en la mano una lanza, forrada de género rojo o azul, con una crucecita en la punta y a lo largo globos de trapo envueltos en tules de colores. En el centro de la procesión venían, en montón informe, los allis. A la cabeza, como los que en las procesiones católicas llevan el palio, iban los allis tradicionales, aquellos que ejercían el cargo hereditariamente. El primero de ellos era el Inca, un pobre viejo, arrugado y andrajoso. Marchaba bajo un arquito forrado de género y con globos de trapo a lo largo, y cuyas puntas dos allis sostenían gravemente. El Inca tocaba un tambor muy pequeño, casi como de juguete. ${ }^{34}$
}

La procesión culminaba en la esquina noroeste de la plaza donde se levantó la primera Casa de Gobierno, sede del Ejecutivo, que popularmente llamaban cabildo. Allí el Inca era recibido por el gobernador y este era homenajeado cantándosele una alabanza en quechua.

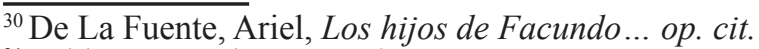

${ }^{31}$ Valdés, Carmelo B., Tradiciones Riojanas ... op. cit., p. 39.

${ }^{32}$ González, Joaquín Víctor, Mis Montañas ... op. cit., p. 96.

${ }^{33}$ Gálvez, Manuel, La Maestra Normal... op. cit., p. 285.

${ }^{34}$ Ibídem, p. 284.
} 
El Inca como líder del pueblo indígena, reafirmaba la autoridad de los españoles, y la aceptación que los indios hacían de su religión, rindiendo homenaje al santo, y al Alcalde del Mundo, de quién el alcalde local, y más tarde el gobernador, derivaban su legitimidad. ${ }^{35}$

Se puede presumir que esta costumbre protocolar habría nacido alrededor de 1850 , en época del Gobierno federal, para congraciarse con la autoridad, ante el fuerte personalismo y manejo autoritario de todo lo que pasaba en la provincia. Este saludo, conllevaba el pedido de venia para realizar desfiles, juegos, y justas de destreza dentro de la ciudad. El Inca con los allis, quizás por su condición pobre, comenzaron a saludar a las religiosas y religiosos de los conventos, que les alojaban o colaboraban con vestimenta para el Niño Alcalde. La celebración poco a poco comenzaba a perfilarse como fiesta de san Nicolás, en detrimento del Niño Alcalde y del Inca y sus allis. La guardia de honor que avanzaba en dos filas con sus banderas (los alféreces) comenzaron a llegar montados en cabalgaduras y, poco a poco, fueron adquiriendo preeminencia. El alférez mayor fue simbólicamente la máxima autoridad de la celebración, por encima del Inca. Esta diferenciación también fue social, pues ellos eran integrantes de familias blancas de la ciudad y promesantes de san Nicolás; esto dio lugar con el tiempo a que reclamaran para sí mismos la representación de la élite, como viejos caballeros españoles, relegando al Inca y a los allis a la representación del pueblo.

La élite local que festejó el triunfo unitario veía con temor y desdén la fiesta, sobre todo por el descontrol, sosteniendo que se trataba de una costumbre colonial que la modernidad no había podido borrar y pronosticaba que poco a poco declinaría hasta desaparecer junto con los gauchos $^{36}$, usando siempre conceptos muy descalificantes. La Iglesia fue más misericordiosa en general a la hora de juzgar la celebración, aunque hubo también algún vicario que prohibió la entrada al templo, o pretendió incautar las imágenes. Sin embargo, primó desde el comienzo del siglo xx la idea de encauzarla, darle una forma más estrictamente religiosa y de alguna manera institucionalizarla.

La derrota del federalismo por los unitarios, ahora llamados liberales, significó también la derrota de los sectores populares por parte de las élites, y el triunfo en todos los órdenes de la dicotomía civilización o barbarie. Esta opción puso al orden —o sea regulación de todo desborde popular - como única alternativa para avanzar hacia el progreso civilizador. En consecuencia, impuso a la celebración una ritualidad programada para exaltar esos valores, y lograr unanimidad en la construcción del universo simbólico. Se impuso una doctrina religiosa dogmática, basada en ritos canónicos sobre las tradiciones religiosas indígenas heredadas. Miembros de la élite se incorporaron como alféreces y nació así el protagonismo de estos como civilizados caballeros españoles, por encima de los allis, o sea, el salvajismo indígena.

\footnotetext{
${ }^{35}$ De La Fuente, Ariel, Los hijos de Facundo... op. cit., p. 189.

${ }^{36}$ González, Joaquín Víctor, Mis Montañas... op. cit.; Gálvez, Manuel, La Maestra Normal... op. cit.
} 
El comienzo del siglo xx vio declinar hasta desaparecer la fiesta oficial de san Nicolás blanco, mientras crecía el fervor por la celebración del llamado Encuentro; y entendió la Iglesia que la fuerza espiritual de estas fiestas patronales, que ya no tenían carácter local pues llegaban promesantes de otras provincias lejanas, debía ser encauzada definitivamente de forma canónica y poco a poco comenzó a tener presencia, en principio para inciensar las imágenes y luego para acompañarlas. Ya nadie discutió, como antes había sucedido, el derecho del Niño Alcalde de pernoctar la noche del 31 de diciembre en la matriz y el primer día del año, rodeando la plaza por lados diferentes encontrarse con san Nicolás frente a la Casa de Gobierno distante dos cuadras, a las 12 en punto del mediodía. Insensiblemente el carácter de fiesta popular fue desapareciendo, como se había pronosticado, pero para transformarse en una celebración religiosa.

\section{Tiempos modernos}

Se concatenaron una serie de hechos en este momento para modificar la ritualidad. Desde 1905, al comienzo de la construcción del nuevo edificio para la matriz, san Nicolás negro pasó a ser titular del mismo, ocupando el altar mayor. En 1920 la misma imagen negra fue coronada por disposición del papa Benedicto XV y en 1934 se creó la Diócesis de La Rioja, lo que reforzó la devoción a san Nicolás y enalteció la figura del santo patrono aureolado por el papa. Paralelamente, en 1926, la imagen del Niño Alcalde fue entregada en custodia permanente a los franciscanos, teniendo casa en el templo de esa orden. Finalmente, en 1937 se construyó una nueva Casa de Gobierno casi lindante al templo de San Nicolás. Estos cambios modificaron sustancialmente los recorridos procesionales y la simbología. Ya no se realizaba una fiesta popular, tampoco se organizaban ferias, ni dos procesiones de similar recorrido. Desde esta época san Nicolás solo sale a la puerta de su templo a esperar al Niño Alcalde, quien peregrina varias cuadras para visitarlo. La curia preside la salida de san Nicolás, y los franciscanos acompañan al Inca y a sus allis.

El siglo xx, consecuentemente, arrancó con la participación directa de la jerarquía eclesiástica, quienes se unieron a la festividad con aparente espontaneidad con el fin de incensar las imágenes, dándole un sentido más litúrgico a la festividad. El vicario Abel Bazán y Bustos, riojano pero dependiente aún de la Diócesis de Córdoba, será un fuerte impulsor de las celebraciones en honor a san Nicolás, perdiéndose el sentido interétnico de la fiesta. Pasaron a ser celebraciones patronales, al punto que cuando publicó su libro sobre la celebración, quien como seminarista fue el primer difusor y participante, el presbítero Vera Vallejo, lo tituló Las 
Fiestas de San Nicolás en La Rioja ${ }^{37}$. Además una Iglesia muy tradicional y aristocrática, de la mano de los primeros obispos diocesanos, favoreció la visibilización del poder, que reproducía el orden social con una impronta discriminadora en lo étnico, social y económico.

La nueva Diócesis de La Rioja, necesitada de imponer autoridad; reforzó el santoral local como estrategia, y actuó sobre las órdenes religiosas un tanto díscolas, impulsando el homenaje a su patrono negro, con la aureolización papal y las fiestas de invierno. La ceremonia pasó a estar presidida por el clero diocesano portando la cruz procesional, que visiblemente antecedía a la imagen de san Nicolás. La comunidad franciscana, a su vez, se encolumnó detrás del Niño Alcalde, figura a la que trató de apuntalar en la devoción popular en su puja por protagonismo, incorporando a la procesión la imagen de san Francisco Solano con el agregado de un amañado violín, instrumento con el que decían habría congregado y calmado a los indígenas. La institucionalización del Encuentro en dos procesiones bien diferenciadas, y con cierto grado de antagonismo entre el clero, que las organizaba y acompañaba, llevó a una identificación étnica, social y económica — quizás también política aunque no de forma explícita— que puso a san Nicolás con sus alféreces de un lado, y al Niño Alcalde y los allis del otro.

Los alféreces que acompañan al santo como nobles caballeros, y representan
así las clases elevadas de la ciudad; los Allis con sus huinchas y sus cintas de
color que hacen la corte al precioso Alcalde del mundo, y que representan el
elemento indígena, las clases humildes del pueblo, y su comarca. ${ }^{38}$

Habría influido en la representación simbólica de los estamentos, el hecho de que para primer obispo de La Rioja fue elegido en 1934 Monseñor Ferreira Reinafé, integrante de la élite cordobesa, con varios miembros de la familia en puestos claves de gobierno, prebendas del cabildo eclesiástico, cargos en la curia diocesana y en el seminario, y al frente de curatos de primer rango. Además, varios parientes cercanos le precedieron como vicarios foráneos de La Rioja. Este obispo imprimió a su gestión una notoria ideología elitista.

Otro actor importante es el gobierno del Estado provincial en formación, siguiendo el modelo nacional.

Las autoridades civiles adhirieron al nuevo orden, observando el encuentro de las imágenes que se producía frente a la sede gubernamental, desde una posición privilegiada en las escalinatas de la nueva Casa de Gobierno. De alguna manera, su participación convalidaba la visión elitista del obispado, e incorporaba la élite local a la celebración, legitimándose mutuamente.

Ello significó el empoderamiento oficial de las élites sobre san Nicolás, la fiesta y, en última instancia, sobre la sociedad de La Rioja. Los otrora integrantes principales, alféreces y allis, se transformaron en sendas cofradías de la diócesis, regladas en sus obligaciones y

\footnotetext{
${ }^{37}$ Vera Vallejo, Juan Carlos, Las fiestas de San Nicolás... op. cit.

${ }^{38}$ Ibídem, p. 14. Resaltado del autor.
} 
dependientes del vicario de la catedral, quien fue desde entonces el gran regidor de la ceremonia, estableciendo el rito; aunque vale decirlo, al principio se respetó básicamente la tradición, pero con un cambio que fue fundamental: la incorporación de las autoridades civiles que aseguraron el patronazgo oficial de san Nicolás, el reconocimiento a la nueva diócesis y la autoridad del obispo. Simbólicamente los alféreces, desde ese momento, serán presentados oficialmente como los representantes del "pueblo blanco", los herederos de los conquistadores, los que tendrán preeminencia, mientras que el Inca y los allis, antes dueños de la fiesta, serán en esta ritualidad solamente los invitados, los descendientes de los pueblos originarios tolerados y recibidos en su casa por el magnánimo santo patrono de la ciudad. Es aquí donde tuvo mucho que ver la mentalidad aristocrática de los primeros obispos diocesanos, provenientes de familias con prosapia y apellidos ilustres.

Hacia 1970, ya era muy notoria la influencia eclesial sobre la celebración, que pasó a ser presidida por el obispo y fue totalmente intervenida por el clero, que actuó sobre la tradición, consolidó al poder político en ella incorporando como nuevo protagonista la figura del intendente, el que lógicamente comprendió la importancia simbólica de lo que se le ofrecía para legitimarse ante el pueblo. Se agregaron elementos simbólicos, como la llave de la ciudad que se entrega al Niño Alcalde o el libro de los Evangelios con que san Nicolás increpará al poder civil para ordenarle que con esa ley gobierne ${ }^{39}$. También se reforzó el valor simbólico de las genuflexiones frente al Niño Alcalde, como forma de jerarquizar la primacía de Dios sobre cualquier otra figura, pero sobre todo valorando la imagen que en el sentir popular representa a los pobres, desposeídos, y criollos, es decir, el pueblo. Esto cambios fueron impulsados por el obispo Angelelli, influido por el Concilio Vaticano II realizado entre 1962/1965, y la posterior Conferencia General del Episcopado Latinoamericano de Medellín. Consistió no solo en orientar la pastoral hacia el pueblo, sino principalmente desde el mismo pueblo, ayudándolo a expresarse y organizarse. La celebración —que se denominará Tinkunaco, “encuentro" pero revalorizado en lengua originaria - adquiere una significación muy fuerte en lo político por cuanto pretendió abandonar códigos etnocéntricos coloniales.

Apenas designado en la diócesis, Angelelli tuvo en claro el potencial simbólico de la religiosidad popular e impulsó esta importante demostración del pueblo riojano dándole el carácter de repudio a las políticas mesiánicas del gobierno militar de turno, conducido por un militar ultracatólico preconciliar, y este respondió prohibiendo con la fuerza pública la celebración. La élite, oficialista y beneficiada por las medidas del Gobierno militar, respondió igualmente con furibundos ataques al obispo a través del diario $\mathrm{El} \mathrm{Sol}$ - creado para apoyar la política oficial y denostar la pastoral de la Iglesia - tildándolo de comunista, y organizando violentos actos de repudio que culminaron con el asesinato de Angelelli por las FF.AA. apenas instaurado el nuevo golpe cívico-militar de Videla. El asesinato fue la respuesta por la prédica

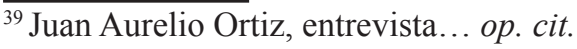


diocesana contra el despojo a que los sectores populares eran sometidos por la élite tradicional de la provincia, usando, incluso en democracia, sus relaciones económicas y redes de parentesco en el partido gobernante ${ }^{40}$, aunque este se promocionara como de signo nacional y popular.

Un agregado importante a la ritualidad consistió en que la ceremonia, tras el encuentro de las imágenes y las tres genuflexiones, culmine con un gran abrazo fraterno entre todos los asistentes, sin distinción de rangos ni diferencias de ningún tipo. Esto tendrá un valor simbólico muy fuerte y merece un análisis detenido. El abrazo implicaba para Angelelli el entendimiento y el reconocimiento "que nos hace hermanos" entre pueblo y gobernantes. La legitimación que otorgaba fue tan importante, que la dictadura militar, luego del asesinato del obispo Angelelli por parte de esas mismas FF.AA., no cambió el Tinkunaco así ritualizado, y ello permitió a los genocidas darse un baño de calor popular y recibir los saludos de alféreces, allis y del pueblo de La Rioja. Pueblo, Gobierno e Iglesia simbolizados como una sola cosa, cuando culminada la última reverencia ritual, todos se mezclan en el abrazo de paz compartido.

El pensamiento del Concilio Vaticano II había calado fuertemente en la Iglesia católica riojana, propendiendo a una batalla cultural que fue política y étnica, en la que se buscó el reconocimiento de derechos y la reivindicación de los sectores populares postergados por la pobreza, impulsando el acceso a las tierras donde vivían y trabajaban, y apoyando una expresión cultural propia. Esta postura de la Iglesia riojana confrontó a las dictaduras cívico-militares que se instauraron en el país y todo el Cono Sur americano con políticas que abolieron las instituciones democráticas, violaron sistemáticamente los derechos humanos, desmantelaron las formas de participación social y prohibieron las organizaciones sociales y sindicales en pos de instaurar un sistema económico neoliberal de concentración de la riqueza. La celebración del Encuentro no podía quedar fuera de esa confrontación, y consolidado ya como Tinkunaco, en lengua originaria, adoptó una ritualidad netamente política y contracultural. Pero si bien con el asesinato por parte de las FF.AA. de Angelelli no se cambiaron las formas exteriores de la celebración, cambió la interpretación simbólica, que en vez de fomentar la realización de las aspiraciones del grupo social marginal, consolidó el concepto de naturalización y aceptación de las diferencias sociales y jerárquicas, la continuidad de la colonialidad ideológica y la concepción autoritaria del manejo del poder. Esta misma ritualidad se mantiene casi hasta el presente, y es usada también por el poder político de la democracia como forma de legitimarse como líderes, mediante la exhibición de sus propias figuras asociadas a las bondades del santo.

\footnotetext{
Los personajes que hacen a la política regional le reconocen al Tincunaco el carácter de espacio social en el cual ellos deben estar presentes; expresado de otra manera, su visibilidad -personal o pictórica- en esta celebración les es imprescindible y está estrechamente ligada al cargo que cada uno de ellos desempeña, o desempeñó. ${ }^{41}$
}

\footnotetext{
${ }^{40}$ Mercado Luna, Ricardo, Enrique Angelelli Obispo de La Rioja, La Rioja, Nexo Grupo Editor, 2010.

${ }^{41}$ Gentile, Margarita, "ACTAS de alianza... op. cit., p. 78.
} 
Al incorporarse el poder político, sus rencillas atravesaron la celebración, y nuevamente en 2008 se cambió el rito para dar participación preponderante al gobernador de la provincia ya que este solo presenciaba la celebración como asistente, opacado simbólicamente por el alcalde de la ciudad, históricamente su rival político. También se comenzó a desarticular cualquier manifestación popular, separando el paso de los portadores de las imágenes de los fieles asistentes mediante un vallado que impedía el acercamiento a las imágenes y a los funcionarios del Estado. Se intentó así mostrar la legitimidad y popularidad de los gobernantes, pero invalidar la emergencia de perspectivas críticas a la acción política desde los diferentes movimientos sociales.

El último capítulo es el proyecto para declaratoria de Patrimonio de la Humanidad por la $\mathrm{UNESCO}^{42}$, para ser utilizado como espectacularización de esta manifestación cultural para disfrute de turistas externos. En la actualidad ya se lo promociona como un producto turístico, incorporando participantes que no son más que espectadores de una dramatización de la que no son parte. Un ritual que se pretende comercializar como producto desprovisto de religiosidad y fe que pudiéramos denominar cotidianas o comunes, con mayor peso de las emociones, que tiende a congelarlo en el estado actual, olvidando que es un proceso histórico de tensiones, de naturaleza inacabada; un proceso social que construye un misticismo religioso por la apropiación colectiva efectiva de valores y significados, y que no puede pensarse solo. El resultado de patrimonizar es enajenarlo de los verdaderos creadores, convertirlo en objeto muerto, y despojado de significados, para que se pueda representar para el turismo muchas veces al año, como ya ha sucedido con otros ejemplos de fiestas populares del noroeste argentino.

\section{Conclusión}

La religiosidad del pueblo riojano tuvo influencia en la conformación de identidades y reivindicaciones étnicas de los sectores populares de la sociedad. Puede rastrearse una línea muy fuerte de identificación, muy clara desde la independencia en adelante, que asume la conciencia social e identificación política de indios y gauchos con la religiosidad católica, sentido de nación formada por las primeras provincias nacidas de fundaciones de ciudades españolas, y el federalismo como expresión de lo nacional y popular. La celebración del Tinkunaco atraviesa en ese contexto toda la historia de La Rioja, provincia y ciudad capital, desde su fundación por europeos en tierra americana para la colonización, explotación de mano de obra originaria y el expolio.

$\overline{42}$ El Independiente, 29 de setiembre de 2016. «http://www.elindependiente.com.ar/pagina.php?id=120132» [Consultado el 9 de mayo de 2018]. 
Esta celebración de fin de año que tuvo un origen colonizador, fue apropiada por el pueblo, luego "civilizada" y corre el riesgo en este siglo XXI de ser entregada como producto de consumo a la economía capitalista. Pero tiene aún a su favor como valor colateral la fuerza de legitimar políticamente, lo que de alguna manera es posible por su consolidación contracultural, que hasta pocos años atrás fuera sentida por los sectores populares como una expresión propia, en la que participaban incluso agnósticos o creyentes de otras religiones, y no como un rito católico. 